Institute of $\mathbf{F}_{\text {ood and }} \mathbf{A}_{\text {gricultural }} \mathbf{S}_{\text {ciences }}$

\title{
Sapote Fruit Fly, Serpentine Fruit Fly, Anastrepha serpentina (Wiedemann) (Insecta: Dipera: Tephritidae) ${ }^{1}$
}

H. V. Weems, Jr. ${ }^{2}$

\section{Introduction}

The sapote fruit fly, Anastrepha serpentina (Wiedemann), sometimes called the serpentine fruit fly, is intercepted frequently in United States ports of entry in various hosts from several countries. It is an important species in Mexico because its larvae infest sapote (Caloca.rpum spp.), sapodilla (Achras zapota), willowleaf lucuma (Lucuma salicifolia) and related fruits. Infestations in tree-ripe fruits frequently are so high that in parts of the country where these fruits are grown, especially in Veracruz, the growers do not permit them to mature on the trees, but pick them green and ripen them artificially to avoid infestation. Fruits so ripened, however, are inferior to tree-ripened fruits. Large numbers of adults have been trapped in the Rio Grande Valley of Texas, but except for one record from grapefruit, no infestation of the species has been found in Texas and the appearance and disappearance of such large adult populations there remains unexplained. Anastrepha serpentina possibly could become a serious pest of tropical fruits in southern Florida if it were introduced into that area.

\section{Synonyms}

Dacus serpentina Wiedemann, 1830

Leptoxys serpentina (Wiedemann), 1843

Urophora vittithorax Macquart, 1851

(Trypeta) Acrotoxa serpentina (Wiedemann), 1873

Acrotoxa serpentina (Wiedemann)

\section{Distribution}

Rio Grande Valley of Texas, Mexico, Costa Rica, Guatemala, Panama, Peru, Trinidad, Brazil, Argentina, Columbia, Ecuador, Guyana, Suriname, Venezuela.

\section{Identification}

\section{Adult}

The adult is a medium sized to fairly large, dark brown fly, marked with pale yellow and orange-brown. Dorsum of thorax dark brown with yellow markings. Wing 7.25 to $8.5 \mathrm{~mm}$ long, the

1. This document is EENY-206 (originally published as DPI Entomology Circular 91), one of a series of Featured Creatures from the Entomology and Nematology Department, Florida Cooperative Extension Service, Institute of Food and Agricultural Sciences, University of Florida. Published: April 2001. This document is also available on Featured Creatures Website at http://creatures.ifas.ufl.edu. Please visit the EDIS Website at http://edis.ifas.ufl.edu and the Entomology and Nematology Department website at http://entnemdept.ifas.ufl.edu/.

2. H. V. Weems, Jr., Florida Department of Agriculture and Consumer Services, Division of Plant Industry, Gainesville, FL.

The Institute of Food and Agricultural Sciences (IFAS) is an Equal Employment Opportunity - Affirmative Action Employer authorized to provide research, educational information and other services only to individuals and institutions that function without regard to race, creed, color, religion, age, disability, sex, sexual orientation, marital status, national origin, political opinions or affiliations. For information on obtaining other extension publications, contact your county Cooperative Extension Service office. Florida Cooperative Extension Service / Institute of Food and Agricultural Sciences / University of Florida / Larry R. Arrington, Interim Dean 
bands predominantly dark brown; costal and $\mathrm{S}$ bands rather broadly coalescent, the hyaline areas to each side of the juncture rarely touching vein $\mathrm{R}_{4+5}$; no distal arm to $\mathrm{V}$ band, the proximal arm slender, entirely separated from $\mathrm{S}$ band. Dorsum of abdomen dark brown marked with brownish yellow and orange. Legs vary from pale yellow to brownish yellow or brown on one side and pale yellow on the other.

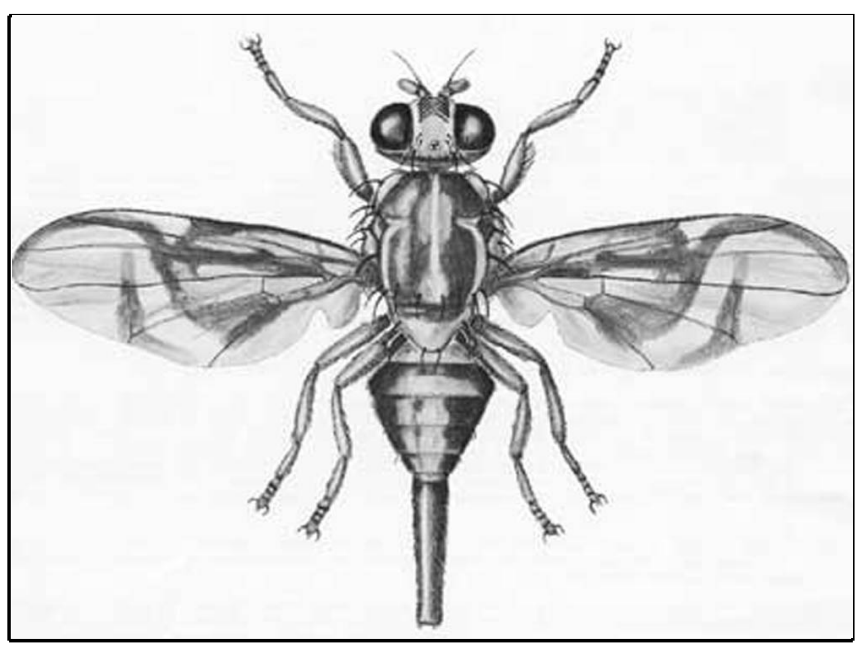

Figure 1. Adult female sapote fruit fly, Anastrepha serpentina (Wiedemann). Also called the serpentine fruit fly. Credits: Division of Plant Industry

Ovipositor sheath of female 3.0 to $3.9 \mathrm{~mm}$ long, orange-brown, rather stout basally and depressed apically, the spiracles about $1.2 \mathrm{~mm}$ from base; ovipositor 2.8 to $3.7 \mathrm{~mm}$ long, the tip with slightly more than apical half minutely serrate.

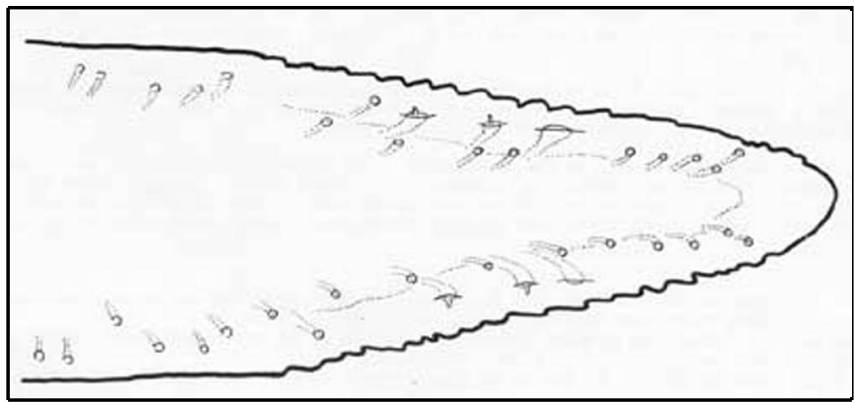

Figure 2. Ovipositor tip of an adult female sapote fruit fly, Anastrepha serpentina (Wiedemann). Also called the serpentine fruit fly. Credits: Division of Plant Industry

\section{Larva}

Mature larva large, 9 to $10 \mathrm{~mm}$ long, $1.5 \mathrm{~mm}$ diameter; of the usual elongate shape. Anterior respiratory organs with external parts somewhat fan-shaped, but nearly flat across the top, with 17 to 19 small, thick, short tubules. For detailed larval characters, see Phillips (1946).

A. serpentina, the type of the genus, is one of a group of four species that differ noticeably in color pattern from other species in the genus. As illustrated by Stone (1942), anomala Stone has the wing pattern as in serpentina, but has a longer ovipositor and a reduced dark pattern on the pleura and abdomen; ornata Aldrich has the costal and V bands separated; pulchra Stone has a large black spot in the disk of the wing.

\section{Life History and Habits}

Females may oviposit up to 600 eggs in about one and a half months. Mature green fruits apparently are preferred. Females have been observed to continue oviposition over periods extending from 21 to 29 weeks under laboratory conditions.

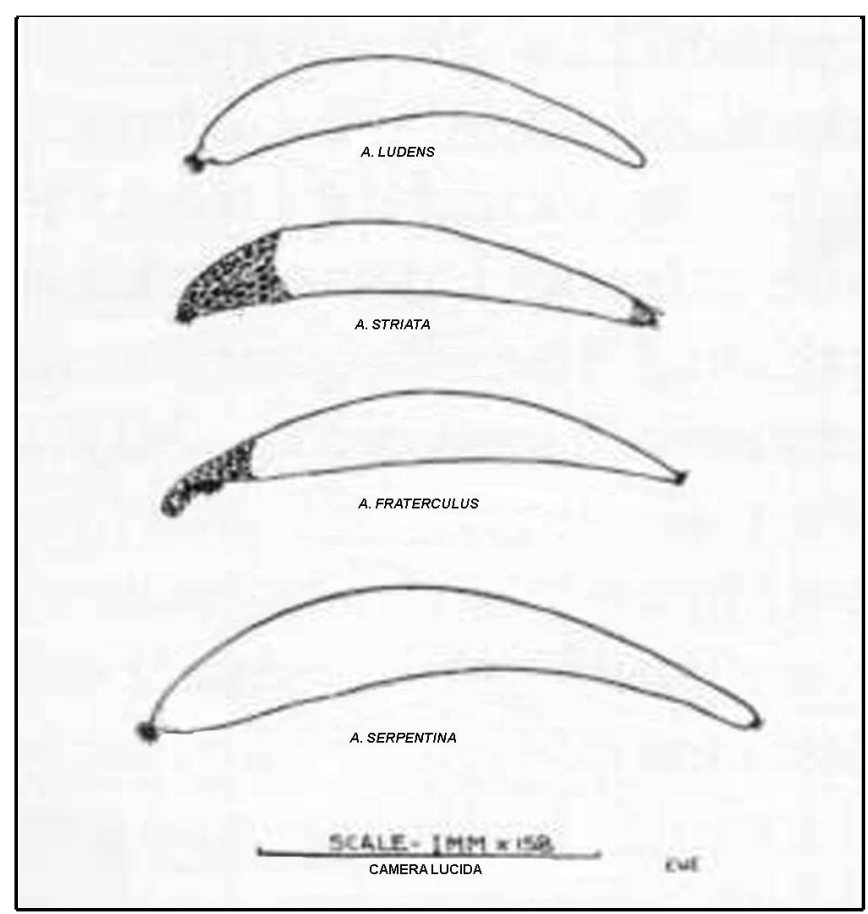

Figure 3. Egg of the sapote fruit fly, Anastrepha serpentina (Wiedemann), compared with other common Anastrepha species. Credits: Division of Plant Industry

\section{Hosts}

\section{Achras zapota, Annona glabra, Bumelia} laetevirens, Calocarpum sapota, Calcocarpum viride, Chrysophyllum cainito, Chrysophyllum panamense, Citrus mitis, Citrus paradisi, Citrus sinensis, Cydonia 
oblonga, Dovyalis hebecarpa, Ficus sp., Labatia

standleyana, Lucuma obovata, Lucuma salicifolia, Malus sylvestris, Mammea americana, Mangifera indica, Manilkara zapotilla, Mimusops coriacea, Persea americana, Prunus persica, Psidium guajava, Pyrus communis, Sideroxylon tempisque, Spondias mombin, Zschokkea panamaensis.

Larvae have been reared experimentally from tomato (Lycopersicum esculentum). The preferred food plants are members of the family Sapotaceae, particularly star-apple (Chrysophyllum cainito) and sapodilla (Achras zapota).

\section{Selected References}

Baker AC, Stone WE, Plummer CC, McPhail M. 1944. A Review of the Mexican Fruitfly and Related Species. U.S. Department of Agriculture Miscellaneous Publication No. 531, Washington, D.C. 155 p.

Norrbom AL. (31 October 2001). Anastrepha serpentina (Wiedemann). The Diptera site. http://www.sel.barc.usda.gov/diptera/tephriti/ Anastrep/serpent.htm (14 January 2002).

Phillips VT. 1946. The biology and identification of trypetid larvae (Diptera: Trypetidae). Memoirs of the American Entomological Society 12, 161 p.

Stone A. 1942. The fruitflies of the genus Anastrepha. U.S. Department of Agriculture Miscellaneous Publication No. 439, Washington, D.C. 112 p.

White IM, Elson-Harris MM. 1994. Fruit Flies of Economic Significance: Their Identification and Bionomics. CAB International. Oxon, UK. 601 p. 